\title{
"Life stand still here": time, epiphany and art in To the Lighthouse
}

Ana Santos*

\section{Abstract}

This article presents a brief look at Virginia Woolf's To the Lighthouse. The text is organized in three main sections: the first one discusses formal aspects of the novel; the second one analyzes Mrs Ramsay's epiphanic moments and how they relate to the main themes in the story (notably to permanence); finally, the third section deals with Lily Briscoe's creative process, which also culminates in an epiphany. Therefore, this work bears on the notion that, in To the Lighthouse, artistic experience and epiphanic experience are equivalent, insofar as both aim to stop the flow of time.

Keywords: Epiphany. Artistic creation. Time. Virginia Woolf. To the Lighthouse.

\section{Introduction}

Published in 1927, To the Lighthouse is one of Virginia Woolf's most critically acclaimed novels, and deservedly so. Inspired by the author's childhood memories and centered on the ethereal figure of Mrs Ramsay, the story is a vivid representation of the power of life and the attempt to capture it through art. The novel is divided into three sections: "Part One: The Window", "Part Two: Time Passes" and "Part Three: The Lighthouse".

In Part One, we meet the Ramsays and a few guests at their summer home in the Hebrides, on the Isle of Skye ${ }^{1}$ (off the west coast of Scotland): Mr and Mrs

\footnotetext{
Doutoranda e mestra em Letras - Estudos de Literatura pela Universidade Federal do Rio Grande do Sul. Graduada em Comunicação Social - Jornalismo pela mesma instituição, onde atua como revisora. É autora de $\mathrm{O}$ que faltava ao peixe (Libretos/Fumproarte, 2011), contemplado com a Bolsa Funarte de Estímulo à Criação Artística, Móbile (Patuá, 2017), finalista do Prêmio Açorianos de Literatura, e Fabulário (Confraria do Vento, 2019), vencedor do Prêmio Governo de Minas Gerais de Literatura. E-mail: oquefaltavaaopeixe@ gmail.com
}

Data de submissão: 23 dez. 2019 - Data de aceite: 15 fev. 2020 http://dx.doi.org/10.5335/rdes.v16i1.8998 
Ramsay, an upper-class couple; their eight children; Lily Briscoe, a painter; Charles Tansley, a philosophy student (Mr Ramsay's pupil); Minta Doyle and Paul Rayley, two young people who end up getting engaged; William Bankes, a botanist; and Augustus Carmichael, a poet.

Several small events happen during the afternoon. James, the Ramsays' youngest son, wants to visit the lighthouse across the bay the next morning, but his father tells him that the weather will be bad. Lily begins a portrait of Mrs Ramsay, which she will only finish a decade later: in the drawing-room, sitting in a window with James at her knee, Mrs Ramsay reads him a fairy tale, while the painter observes them from the lawn. In the evening, a dinner party organized by Mrs Ramsay becomes the high point of Part One (and perhaps of the whole novel): as perceived by the hostess, it is an epiphanic moment of communion among the otherwise conflicting guests.

Part Two covers ten years in fourteen pages. World War I breaks out across Europe, and the Ramsays no longer vacation in their summer house. We are told very casually about the sudden deaths of Mrs Ramsay and two of her children (Andrew and Prue). The abandoned house is the protagonist here: time and nature act upon it day after day, destroying everything that the family once held dear. Eventually, Mrs
$\mathrm{McNab}$ (the housekeeper), with the help of some other women, sets the house in order. The Ramsays will return.

The events of Part Three happen in the course of one morning. Lily begins her painting once again, trying to retrieve Mrs Ramsay's image from her memory. On the lawn where she stood ten years before, she makes the final brush stroke as James at last reaches the lighthouse, accompanied by his father and his sister Cam.

Like the novel, this essay is organized in three main sections: 1) a brief analysis of some formal aspects of the story; 2) some comments on Mrs Ramsay's epiphanic moments and how they relate to the main themes in the novel (notably to permanence); 3) a similar look at Lily Briscoe's thoughts on life and art, which culminate in her final vision.

\section{"In the midst of chaos there was shape": some formal aspects}

Throughout most of the novel, Woolf makes use of the stream-of-consciousness technique and of variable internal focalization (PRINCE, 2003), which indicates the existence of a heterodiegetic narrator who presents the perceptions of different characters/focalizers. David Lodge (1993, p. 43) associates the stream of consciousness with free indirect style, pointing out that this type of narration 
[...] renders thought as reported speech (in the third person, past tense) but keeps to the kind of vocabulary that is appropriate to the character, and deletes some of the tags, like "she thought," "she wondered," "she asked herself" etc. that a more formal narrative style would require. This gives the illusion of intimate access to a character's mind, but without totally surrendering authorial participation in the discourse.

This means that there is little action in To the Lighthouse: most of the novel happens in the minds of the characters, lingering on the deep significance of seemingly trivial things. The narrator's job thus consists in representing the characters' thoughts.

Luc Herman and Bart Vervaeck (2005, p. 94) state that consciousness is "an abstract and hypothetical construct that often remains irretrievable". Therefore, "[...] consciousness is considered the deep structure, while its representation is the superficial manifestation of that structure". Virginia Woolf's profound knowledge of human nature, however, allows her to virtually erase the difference between experience itself and its reproduction - through her delicately woven poetic prose, she almost transcends the "actual" thought or feeling.

The use of epiphany plays an essential role in capturing the characters' perceptions, momentarily stopping the flow of time. Lodge (1993, p. 146-147) defines the term as follows:

\begin{abstract}
An epiphany is, literally, a showing. In Christian terminology it denotes the showing of the infant Jesus to the three Magi. James Joyce [...] applied the word to the process by which a commonplace event or thought is transformed into a thing of timeless beauty by the exercise of the writer's craft: "when the soul of the commonest object seems to us radiant," as his fictional alter ego, Stephen Dedalus, says. The term is now loosely applied to any descriptive passage in which external reality is charged with a kind of transcendental significance for the perceiver.
\end{abstract}

In To the Lighthouse, even Part Two, which is mostly impersonal and descriptive (except for Mrs McNab's memories and perceptions), contains passages that are on the verge of epiphany. It is almost as if the author, despite her neutrality, suddenly realized how human and perishable her characters are:

Whatever else may perish and disappear what lies here is steadfast. Here one might say to those sliding lights, those fumbling airs, that breathe and bend over the bed itself, here you can neither touch nor destroy. Upon which, wearily, ghostlily, as if they had feather-light fingers and the light persistency of feathers, they would look, once, on the shut eyes and the loosely clasping fingers, and fold their garments wearily and disappear (WOOLF, 2002, p. 94$){ }^{2}$

It is also important to notice that Part Two, because of its difference in length and style, is a key element in the construction of the novel. It functions as a central line uniting two similar masses - that is, a concise description of a ten- 
year interval connecting the extensive accounts of two single days.

Thomas G. Matro (1984) points out the similarity between the structure of the novel and that of Lily Briscoe's painting $^{3}$. In Part One, Lily expresses her intention to "connect this mass on the right hand with that on the left" (p. 39), but she is afraid to break the unity of the whole. At the end of the book, it is only when she draws "a line there, in the centre" (p. 154) that her picture is finally completed - and so is the novel. We could thus say that Lily's painting is a symbol of the novel itself and, even more importantly, a symbol of artistic creation in general.

\section{"The long steady stroke": Mrs Ramsay's illuminations}

Although Lily struggles to reach Mrs Ramsay and to capture her essence, the reader gets a good grasp of the character through several epiphanic passages in which she is the focalizer. Some of her epiphanies will be discussed in this section, starting with the one on page 12 :

[...] the monotonous fall of the waves on the beach, which for the most part beat a measured and soothing tattoo to her thoughts and seemed consolingly to repeat over and over again as she sat with the children the words of some old cradle song, murmured by nature, 'I am guarding you - I am your support,' but at other times suddenly and unexpectedly, especially when her mind raised itself slightly from the task actually in hand, had no such kindly meaning, but like a ghostly roll of drums remorselessly beat the measure of life, made one think of the destruction of the island and its engulfment in the sea, and warned her whose day had slipped past in one quick doing after another that it was all ephemeral as a rainbow - this sound which had been obscured and concealed under the other sounds suddenly thundered hollow in her ears and made her look up with an impulse of terror.

Here the sound of the sea is at first associated with safety and stability: it reassures Mrs Ramsay that all is well, that life goes on in its usual, comforting pace. The "revelation" comes when she realizes that the roar of the waves actually announces the fragility of everything she knows - including that small island. This happens "especially when her mind [raises] itself slightly from the task actually in hand", that is, when she is caught off-guard for not being completely immersed in some daily chore. Thus the fall of the waves, concealed under other familiar sounds, has a numbing effect on Mrs Ramsay which helps her move on. Only when she truly listens to it does she feel how powerful and terrifying it is. Mrs Ramsay is then reminded of death - and of the fact that life is always hanging by a thread.

At another point in the novel, she reflects that "[n]ot as oneself did one find rest ever [...] but as a wedge of darkness" 
(p. 45). She can only achieve that state of peace when life "sinks down" and she feels completely detached from herself:

[...] and there rose to her lips always some exclamation of triumph over life when things came together in this peace, this rest, this eternity; and pausing there she looked out to meet that stroke of the Lighthouse, the long steady stroke, the last of the three, which was her stroke, for watching them in this mood always at this hour one could not help attaching oneself to one thing especially of the things one saw; and this thing, the long steady stroke, was her stroke. Often she found herself sitting and looking, sitting and looking, with her work in her hands until she became the thing she looked at - that light for example. And it would lift up on it some little phrase or other which had been lying in her mind like that - 'Children don't forget, children don't forget' - which she would repeat and begin adding to it, It will end, it will end, she said. It will come, it will come, when suddenly she added: We are in the hands of the Lord (p. 46).

Watching the lighthouse, Mrs Ramsay is one with its long steady stroke. Here light and darkness come together: the freedom of being a core of darkness is equivalent to the freedom of being a stroke of light. These two opposites are equally incorporeal and thus can be eternal. Ordinary life creeps in, though, reminding her that James will never forget his father's refusal to take him to the lighthouse. She then thinks of the transience of life (it will end) and the inevitability of death (it will come), trying to find consolation in the fact that we are "in the hands of the Lord", that is, we are not completely helpless because life is not random: a divine being governs and organizes it. This belief is denied in the next paragraph:

But instantly she was annoyed with herself for saying that. Who had said it? not she; she had been trapped into saying something she did not mean (p. 46).

Mrs Ramsay experiences this sensation of eternity once more at the dinner party - generally considered the novel's climax -, when she has what is perhaps her greatest epiphany (beautifully crafted by Woolf):

Everything seemed right. Just now (but this cannot last, she thought [...]), just now she had reached security; she hovered like a hawk suspended; like a flag floated in an element of joy which filled every nerve of her body fully and sweetly, not noisily, solemnly rather, for it arose, she thought, looking at them all eating there, from husband and children and friends; all of which rising in this profound stillness [...] seemed now for no special reason to stay there like a smoke, like a fume rising upwards, holding them safe together. Nothing need be said; nothing could be said. There it was, all round them. It partook, she felt, carefully helping Mr Bankes to a specially tender piece, of eternity [...]; there is a coherence in things, a stability; something, she meant, is immune from change, and shines out (she glanced at the window with its ripple of reflected lights) in the face of the flowing, the fleeting, the spectral, like a ruby [...]. Of such moments, she thought, the thing is made that remains for ever after. This would remain (p. 75-76).

Sharing a delicious boeuf en daube by candlelight, the Ramsays and their 
guests reach a state of unity. Mrs Ramsay can see it all very clearly: like a hawk, a flag, or the Lord himself, she hovers over her loved ones, watching them, protecting them from harm. She overflows with joy - a kind of joy that cannot last, although it will echo in the house for ever. Time stands still right then, when Mrs Ramsay is overcome with love for those people who are doing something as trivial as eating. This feeling of warmth stays there "like a smoke, like a fume rising upwards", perhaps connected to the candles and the steam from the food. By helping $\mathrm{Mr}$ Bankes to a tender piece of the boeuf en daube, she is also helping him to a piece of eternity. There are moments which are solid and shining, despite the much more numerous ephemeral ones. This is one of them, and Mrs Ramsay reigns over it - like an artist, she perceives a coherent pattern and tries to make it permanent.

Karl Jaspers (1967, p. 111) states that "[t]hough the moment is temporal, it nevertheless participates, when fulfilled existentially, in time-transcending eternity". This means that the dinner party at the Ramsay's summer home might still be happening in a dimension beyond human understanding. Maybe this is what Mrs Ramsay intuited all along. She soon takes the role of the lighthouse, surveying and illuminating the room:
It could not last she knew, but at the moment her eyes were so clear that they seemed to go round the table unveiling each of these people, and their thoughts and their feelings, without effort, like a light stealing under water so that its ripples and the reeds in it and the minnows balancing themselves, and the sudden silent trout are all lit up hanging, trembling. So she saw them; she heard them; but whatever they said had also this quality, as if what they said was like the movement of a trout when, at the same time, one can see the ripple and the gravel, something to the right, something to the left; and the whole is held together; for whereas in active life she would be netting and separating one thing from another [...]; she would be urging herself forward; now she said nothing. For the moment, she hung suspended (p. 77).

According to Thomas G. Matro (1984, p. 218),

[...] Mrs. Ramsay's sense of the guests seems to come not from their conversation but from the pattern: "something to the right, something to the left; and the whole is held together." Like the lighthouse, Mrs. Ramsay, with the guests arranged around her, is in a focal position, a kind of "central line," and this arrangement surely recalls Lily's language [...] when she explains her aesthetic assumptions.

The water imagery in this passage is also worthy of note: ripples, reeds, minnows, trouts, and Mrs Ramsay "netting and separating one thing from another", like a fisherwoman. She can see beneath the surface of people, catching their hidden quintessence - a live fish, trembling.

Even when the moment ends and Mrs Ramsay feels it has become "already 
the past" (p. 80), she is aware of its importance and of the lasting effect it will have on people:

Yes, that was done then, accomplished; and as with all things done, became solemn. Now one thought of it, cleared of chatter and emotion, it seemed always to have been, only was shown now, and so being shown struck everything into stability. They would, she thought [...], however long they lived, come back to this night; this moon; this wind, this house: and to her too. It flattered her, where she was most susceptible of flattery, to think how, wound about in their hearts, however long they lived, she would be woven; and this, and this, and this, she thought, going upstairs, laughing, but affectionately, at the sofa on the landing (her mother's); at the rocking-chair (her father's); at the map of the Hebrides (p. 82).

Just like great works of art seem to have always existed - even if only in potential form -, this moment may have long been painted on the wall of time. Mrs Ramsay strikes a match in the dark (an image later used by Lily) and allows us to see it. She appropriates elements of nature and makes them part of her personal triumph: not the usual moon or the usual wind, but this moon, this wind. Objects which are part of her family's story - her mother's sofa, her father's rocking-chair - will now be remembered by her guests as well (especially by Paul and Minta, who have just gotten engaged). Above all, she will be remembered until the end of their lives - which is a way of postponing death, because a person is not really gone while he or she is woven in someone's heart.

This wish to create beauty and permanence is confirmed by the scene in which Mrs Ramsay wraps her shawl around the horrid boar's skull in the nursery. She tells her little daughter Cam that it looks lovely now and that the fairies will love it: "it was like a bird's nest, it was like a beautiful mountain such as she had seen abroad, with valleys and flowers and bells ringing and birds singing and little goats and antelopes" (p. 83). Here Mrs Ramsay is trying to hide the ultimate truth: hideousness and decay. It is unveiled in Part Two, though, as the folds of her shawl loosen one by one over the years until idly, aimlessly, it just swings to and fro in the deserted house.

\section{"But this is what I see": brief look at Lily Briscoe}

Lily's difficulty in painting Mrs Ramsay does not reside exclusively in the fact that her object is a complex and unique character. Italo Calvino (1988, p. 75) points out that

[...] in representing the density and continuity of the world around us, language is revealed as defective and fragmentary, always saying something less with respect to the sum of what can be experienced.

Although the author is referring to literature, this can be said of any kind of 
artistic expression. In this section, some moments of Lily's creative process will be discussed.

The painter's struggle starts on page 14:

She could see it all so clearly, so comman-
dingly, when she looked: it was when she
took her brush in hand that the whole thing
changed. It was in that moment's flight
between the picture and her canvas that the
demons set on her who often brought her to
the verge of tears and made this passage
from conception to work as dreadful as any
down a dark passage for a child. Such she
often felt herself - struggling against terrific
odds to maintain her courage; to say: 'But
this is what I see; this is what I see, and
so to clasp some miserable remnant of her
vision to her breast, which a thousand forces
did their best to pluck from her. And it was
then too, in that chill and windy way, as she
began to paint, that there forced themselves
upon her other things, her own inadequacy,
her insignificance [...].

This is an accurate and poignant description of the main elements involved in the creation of art. Lily's process could well be a symbol of every artist's search: reproducing with exactitude what he or she sees and feels, so that others will be able to experience this instant of revelation with the same intensity. At times inspiration is not enough: one is overcome with emotion, but simply cannot turn it into art. This passage from conception to work can be painful, especially if the artist does not have the technique or the talent to make it. The fact that Lily seems to be dealing with abstract art might complicate things even further - making an abstract picture is as close as a painter gets to creating poetry, an art in which all meaning is volatile. After fighting "a thousand forces", what is left to Lily is just "some miserable remnant of her vision". She thus begins questioning her worth and her right to create art: how could she, in her insignificance, be one of the chosen few?

Mrs Ramsay herself does not take Lily's painting very seriously, something the artist never finds out. She is constantly bothered, though, by Charles Tansley's sexist mantra ("women can't paint, women can't write"), which aggravates her insecurities:

She could have wept. It was bad, it was bad, it was infinitely bad! She could have done it differently of course; the colour could have been thinned and faded; the shapes etherealised [...]. But then she did not see it like that. She saw the colour burning on a framework of steel; the light of a butterfly's wing lying upon the arches of a cathedral. Of all that only a few random marks scrawled upon the canvas remained. And it would never be seen; never be hung even, and there was Mr Tansley whispering in her ear, 'Women can't paint, women can't write...' (p. 35).

The difference between what Lily conceives and what she actually accomplishes is significant. She knows exactly what her picture should look like: something at once fluid and solid, light and heavy, hence the contrasting images (burning colour versus steel, butterfly 
versus cathedral). Yet of all that "only a few random marks scrawled upon the canvas remained". Perhaps these random marks have their value, though, since they foreshadow the sad truth: Mrs Ramsay's glory will be reduced to a bunch of old clothes and objects in an abandoned house.

When Lily restarts her painting, she feels the same excitement and fear she had experienced ten years before:

[...] she took her hand and raised her brush. For a moment it stayed trembling in a painful but exciting ecstasy in the air. Where to begin? - that was the question; at what point to make the first mark? One line placed on the canvas committed her to innumerable risks, to frequent and irrevocable decisions. All that in idea seemed simple became in practice immediately complex; as the waves shape themselves symmetrically from the clifftop but to the swimmer among them are divided by steep gulfs and foaming crests. Still the risk must be run; the mark made (p. 118).

As if painting were living, Lily is afraid to make the wrong choice. She can only move forward - there is no going back to the blank canvas. Seen from a distance, the image that inspires her is mild and clear. As she approaches it, though, it reveals itself as a force of nature which she cannot tame. Still she wants to give her small contribution to the world: her picture may not be a masterpiece, but it is hers and no one else's.
Lily's memory of a pleasant morning on the beach with Mrs Ramsay and Charles Tansley reiterates some of the novel's main themes:

What is the meaning of life? That was all - a simple question; one that tended to close in on one with years. The great revelation had never come. The great revelation perhaps never did come. Instead there were little daily miracles, illuminations, matches struck unexpectedly in the dark; here was one. This, that and the other; herself and Charles Tansley and the breaking wave; Mrs Ramsay bringing them together; Mrs Ramsay saying 'Life stand still here'; Mrs Ramsay making of the moment something permanent (as in another sphere Lily herself tried to make of the moment something permanent) - this was of the nature of a revelation. In the midst of chaos there was shape; this eternal passing and flowing (she looked at the clouds going and the leaves shaking) was struck into stability (p. 120).

Creating art is as much an attempt at permanence as Mrs Ramsay's way of living was: an effort to find meaning in the absurdity of existence and to transcend mortality. This cannot be accomplished but in the form of "little daily miracles, illuminations, matches struck unexpectedly in the dark", that is, of epiphanic moments. Therefore, epiphanies can be associated with inspiration and thus be considered a prerequisite for making a work of art. Lily herself was part of the unity Mrs Ramsay was able to engender, in the sense that even her antipathy towards Charles Tansley was momentarily 
forgotten: that morning on the beach, they all achieved some kind of wholeness.

Only when Lily embraces the imperfection of her painting does she start moving towards its completion. She reflects that "[o]ne might say, even of this scrawl, not of that actual picture, perhaps, but of what it attempted, that it 'remained for ever"' (p. 133). Thomas G. Matro (1984, p. 214) highlights the importance of this realization when he states that

[a]s the novel proceeds, [the] notion of "vision" as a special experience to be fixed in a painting changes, referring in the end to the process and effort of perception rather than to a particular image, an idealist vision, or an achieved aesthetic order.

Just as Virginia Woolf completes her novel, Lily Briscoe completes her painting - which might be interpreted as a mise en abyme:

There it was - her picture. Yes, with all its greens and blues, its lines running up and across, its attempt at something. It would be hung in the attics, she thought; it would be destroyed. But what did that matter? she asked herself, taking up her brush again. She looked at the steps: they were empty; she looked at her canvas: it was blurred. With a sudden intensity, as if she saw it clear for a second, she drew a line there, in the centre. It was done; it was finished. Yes, she thought, laying down her brush in extreme fatigue, I have had my vision (p. 154).

The sentences "it was done" and "it was finished" instantly remind us of Mrs Ramsay's thoughts after the dinner party: "that was done then, accompli- shed". It does not matter that Lily's painting will eventually be forgotten or destroyed - the important thing is that it once existed. It is at this point that art comes closest to life: the very act of creating makes it worthwhile. Mrs Ramsay may not be on the drawing-room steps any longer, but she has been there - and, in Lily's vision, that is where she remains.

\section{Some final thoughts}

The fact that To the Lighthouse is one of the greatest novels of the twentieth century makes its analysis a difficult task, mainly because so much has already been written about it. Far from claiming originality, this essay simply aims to offer a subjective reading of some aspects of the book, which will hopefully be of use to those who wish to become acquainted with it.

Virginia Woolf's talent is a rare one: unlike Lily, always so insecure in front of her canvas, Woolf virtually gets to transpose life onto paper. This astonishing novel would deserve a word-for-word analysis if that were possible. Besides time, epiphany and art, there is a wealth of other themes and motifs to be explored in the book: love; parental relationships; childhood; gender issues; death; the sea; the lighthouse etc.

Although academic essays may fail in capturing the essence of art, it is 
always positive to remind the universe of the importance of works such as To the Lighthouse. Before we perish, each alone, it is worth evoking the memory of those little illuminations mentioned by Lily. They are, perhaps, encrypted clues towards the answer to our deepest question - life may have a meaning, after all.

\section{"Life stand still here": tempo, epifania e arte em To the Lighthouse}

\section{Resumo}

Este artigo apresenta um breve estudo do romance To the Lighthouse, de Virginia Woolf. O texto está organizado em três seções principais: na primeira delas, tecem-se comentários acerca de aspectos formais da obra; na segunda, são analisados momentos epifânicos vividos pela protagonista (Mrs Ramsay) e a relação desses momentos com os temas centrais do romance, sobretudo com o desejo de permanência; a terceira seção aborda o processo criativo da pintora Lily Briscoe, que também culmina, por sua vez, em uma epifania. Reforça-se, assim, a noção de que, em To the Lighthouse, experiência artística e experiência epifânica são equivalentes, na medida em que ambas visam a interromper a passagem do tempo.

Palavras-chave: Epifania. Criação artística. Tempo. Virginia Woolf. To the Lighthouse.

\section{Notas}

1 Based on St Ives, Cornwall, where Virginia Woolf used to spend summers as a child.

2 Henceforth, whenever a passage from To the Lighthouse is quoted, only the page number will be indicated.

3 Matro also mentions that the notion behind this structure was borrowed from Roger Fry's formalist, postimpressionist aesthetic principles.

\section{References}

CALVINO, Italo. Six Memos for the Next Millennium. Cambridge, Massachusetts: Harvard University Press, 1988.

HERMAN, Luc; VERVAECK, Bart. Handbook of Narrative Analysis. Lincoln: University of Nebraska Press, 2005.

JASPERS, Karl. Philosophy is for Everyman: a Short Course in Philosophical Thinking. New York: Harcourt, Brace \& World, 1967.

LODGE, David. The Art of Fiction. New York: Viking Penguin, 1993.

MATRO, Thomas G. Only Relations: Vision and Achievement in To the Lighthouse. $P M L A$, v. 99, n. 2, p. 212-224, Mar. 1984.

PRINCE, Gerald. A Dictionary of Narratology. Lincoln: University of Nebraska Press, 2003.

WOOLF, Virginia. To the Lighthouse. Introduction and notes by Nicola Bradbury. Hertfordshire: Wordsworth Editions, 2002. 